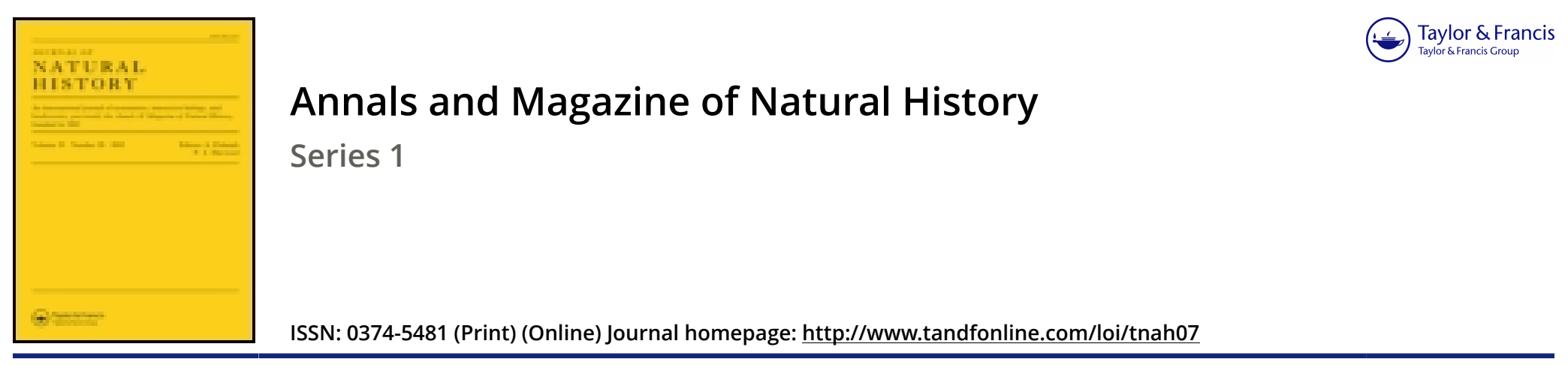

\title{
XLVI.-Record of the discovery of an alligator with several new Mammalia in the freshwater strata at Hordwell
}

\section{Searles Wood Esq. F.G.S.}

To cite this article: Searles Wood Esq. F.G.S. (1844) XLVI.-Record of the discovery of an alligator with several new Mammalia in the freshwater strata at Hordwell , Annals and Magazine of Natural History, 14:92, 349-351, DOI: 10.1080/037454809495192

To link to this article: http://dx.doi.org/10.1080/037454809495192

曲 Published online: 16 Dec 2009.

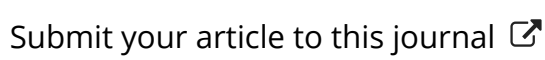

Q View related articles ¿

Citing articles: 5 View citing articles $\widetilde{\pi}$ 
were supposed to consist in the basal portion of the lateral tailfeathers being white, while the $T$. pelagica is described by most authors as having the tail wholly black. I had however for some time suspected that the melitensis and pelagica were identical, having observed in my own specimen of pelagica that the lateral rectrices were in fact white towards the base, though this colour is nearly concealed by the incumbent tail-covers.

By the kindness of Capt. Drummond I am now enabled to set at rest these doubts, having just received from him several specimens of the supposed species named melitensis, obtained at Malta, but which turn out to be quite identical with the Thalassidroma pelagica of the British seas. This opinion is confirmed by Mr. G. R. Gray, to whom I have sent one of Capt. Drummond's specimens, and who assures me that he has compared it with the specimens of the true pelagica in the British Museum, and that he can find no distinctions between them.

Capt. Drummond (who is now at Malta) has communicated to me the following corrections to be made in his papers on the birds of the Ionian Islands and of Crete.

The species entered as Picus major (Annals, vol. xii. p. 418) should be P.leuconotus, - the P. major not being found in Corfu.

The birds which are sold at Malta to the uninitiated for snipes (p. 418) are the Upupa epops, and not (as stated through a misprint) the Yunx torquilla.

The falcon mentioned at p. 423 , as chasing beetles in the evening in Crete, is proved on further examination to be the Falco Eleonora, and not $F$. subbuteo, which last species was not noticed in Crete. Falco Eleonore may also be included, though as a rare bird, in the fauna of the Ionian Islands, a specimen having been obtained from the island of Fano.

XLVI.-Record of the discovery of an Alligator with several new Mammalia in the Freshwater Strata at Hordwell. By Searles Wood, Esq. F.G.S.

Dear Sir, York, Oct. 23, 1844. As the Report in the Athenæum of the late Meeting of the British Association here, does not contain any abstract of the bighly important discoveries made by Mr. Searles Wood in the freshwater strata at Hordwell, perhaps you will find room in the forthcoming Number of the 'Annals' for a brief notice of this gentleman's researches.

Yours, dear Sir, most faithfully, Edward Charlesworth.

Richard Taylor, Esq.

Part of the summer of 1843 was devoted by Mr. Wood to an 
examination of the celebrated freshwater cliff at Hordwell in Hampshire, and upon quitting England in the early part of this year Mr. Wood intrusted to me for publication the new fossils which he had discovered, accompanied by manuscript notes. To these he requested I would append such remarks as a more full examination of the respective specimens might enable me to furnish.

Of the remains in question referable to the Mammalia, the most instructive specimen is an imperfect cranium of a Pachydermatous quadruped, for which Mr. Wood proposes the generic name $\mathbf{M i -}$ crochserus. It comes very near Hyracotherium in the general aspect of the molar teeth, but its size could hardly have exceeded that of the hedgehog (Erinaceus europaus). It had moreover no interspace between the second and first spurious molar, nor between this last-named tooth and that which in Hyracotherium Prof. Owen regards as a canine. The last molar also differs very decidedly in shape from that of Hyracotherium, but until more species of this group are known, generic distinctions can only be regarded as provisional, and in the present case the characters assumed as generic may hereafter prove to be only specific. Most fortunately one ramus of the lower jaw was found with the above, demonstrating that Microchorus has that remarkable prolongation backwards of the angle so strikingly displayed in Choropotamus.

Mr. Waterhouse takes the following view of the dental formula of this genus :-

Incisors $\frac{2-2}{1-1}$; canines $\frac{0-0}{0-0}$; false molars $\frac{4-4}{4-4}$; true molars $\frac{3-3}{3-3}$; $=34$.

1st. The specific name of erinaceus is proposed by Mr. Wood for this new addition to British fossil Mammalia.

2nd. Part of the upper jaw of a very small nondescript mammal, with highly complicated molar teeth, clearly insectivorous, but not sufficiently perfect to decide upon its generic relations*.

3rd. A trifid mammalian tooth cleft nearly to the base of its crown as in the genus Stenorhynchus, and which I believe to be the tooth of a seal.

4th. A mammalian tooth remarkably compressed, with a single lateral lobe. I think this may also be referable to a seal.

* Mr. Flower of Croydon, stimulated by Mr. Wood's success, pursued the investigation of the Hordwell cliff, and along with other interesting fossils obtained a considerable portion of the lower jaw of a small insectivorous mammal, which he was so obliging as to lend to Mr. Wood, that it might be described along with the new mammalia previously discovered. For this fossil I suggested at the Meeting of the British Association the provisional generic term spalacodon. 
5th. A scapula, apparently of the Palcotherium, in fine preservation; also a portion of the upper jaw with several molar teeth in situ.

6th. A great portion of the head of an alligator, having nearly all the upper range of teeth ( 42 in number) remaining, along with the humerus, dermal scutæ and other parts of the skeleton.

This fossil, I think, may be regarded as the most interesting: Saurian relic yet discovered in British or continental tertiary strata. The remains were imbedded in the fine siliceous sand of which the freshwater deposit at Hordwell is chiefly composed, and with the exception of a change in colour and chemical composition, are presented to the study of the palæontologist in a state which would challenge comparison with those of any recent skeleton. Mr. Wood's discovery too constitutes I believe the first authentic record of the occurrence of the alligator in the fossil state. In the same deposit this gentleman found numerous scales and vertebræ of the Lepidosteus, a genus of fishes now associated with the alligator in the new world. Mr. Wood proposes to call the Hordwell alligator $A$. Hantoniensis.*

\section{BIBLIOGRAPHICAL NOTICES.}

Naturgetreue Abbildungen und Beschreibungen der essbaren, schädlichen und verdächtigen Schwämme. Von J. V. Krombholz. Prag, 18311843.

EIGнт parts of this splendid work, containing sixty-two plates, were published, when it was arrested by the death of the author in the course of last autumn. Fourteen more plates however had been engraved before the 'Epicrisis' of Fries was published in which they are quoted, and which appeared in 1836, but was some time previously in the hand of the printer. These we have obtained from Prag through the kindness of $M$. Corda ; and we believe that the drawings from which they were made are lost together with the greater part of the specimens ; there is therefore no probability of their ever being published. The work then must be considered as ending with the sixty-second plate, and we confidently recommend it as a storehouse of excellent figures which are due to the pencil of $M$. Corda, who is no less happy in the delineation of larger objects than in the minute forms of fungi, on which he has thrown so much light; indeed the whole execution of the work is due to him, Krombholz himself having done little more than the editorial part. The figures and dissections, it must be remembered, were made some time before the recent discoveries of the true structure of the hymenium, and at a time when $M$. Corda was neither so practised in the use of the microscope nor possessed of so good an instrument as at present; the analyses therefore are not what one would expect from

- It is Mr. Wood's intention shorly to publish a more detailed account of these fossils, accompanied by illustrations. 